\title{
THE CULTURAL SPACE OF IMPERIAL PROVINCES AS A FACTOR IN PRESERVING ROMAN IDENTITY IN LATE ANTIQUITY
}

\author{
E. V. Litovchenko \\ Belgorod National \\ Research University
}

\author{
E. В. Митовченко \\ Белгородский государственный \\ национальный исследовательский \\ университет
}

\begin{abstract}
This work is dedicated to uncovering the significance of provincial cultural space in the preservation of Roman identity in the fourth and fifth centuries A.D. The author concludes that the provincial elite, having replaced the old Roman aristocracy, sought to preserve the eternal ideal, which for them could not be separated from Rome. The cultural space of some imperial provinces was a factor in the preservation of traditional classical values such as the "imperial idea" (including the concept of "Aeternitas Romae"), rhetorical techniques, and others because of the system of rhetorical education, the high level of urbanization, and the Roman policy of consolidating the local aristocracy.
\end{abstract}

Keywords: Late Antiquity, Roman provinces, Gaul, North African provinces, intellectual elite of the Roman nobility, Ausonius, Rutilius Namatianus, Sidonius Apollinaris, Dracontius, classical tradition.

E-mail: litovchenko[at]bsu.edu.ru

Copyright: (C) 2014 Litovchenko. This is an open-access article distributed under the terms of the Creative Commons Attribution License (CC BY 4.0), which permits unrestricted use, distribution, and reproduction in any medium, provided the original author and source are credited.

удк 93 (3)

\section{КУАЬТУРНОЕ ПРОСТРАНСТВО ИМПЕРСКИХ ПРОВИНЦИЙ КАК ФАКТОР КОНСЕРВАЦИИ РИМСКОЙ ИДЕНТИЧНОСТИ В ПОЗДНЕАНТИЧНУЮ ЭПОХУ}

Аннотация. Статья посвящена выявлению значения культурного пространства имперских провинций в консервации римской идентичности в IV-V вв. н.э. Автор приходит к выводу, что провинциальная элита, заменившая старую римскую аристократию, стремилась сохранить вечный идеал, который для нее был неотделим от Рима. Благодаря системе риторического образования, высокому уровню урбанизации и римской политике консолидации местной аристократии, в позднеантичное время культурное пространство 
некоторых провинций Римской империи являнось фактором консервации традиционных классических ценностей, таких как "имперская идея" (включая концепцию "Aeternitas Romae»), риторические приемы и др.

Ключевые слова: Поздняя Античность, римские провинции, Галмия, Северная Африка, интеллектуальная элита, Авзоний, Рутилий Намациан, Сидоний, Драконций, классическая традиция.

In the present socio-cultural situation the role of the provincial is being reinterpreted, not only as a keeper of traditional cultural values, but as a social environment for the formation and preservation of spiritual and daily lived experience. Such an interpretation is impossible without a foundation in the historical past of mankind, including the history of the provincial Roman Empire.

During the last period of antiquity certain Roman provinces lived practically independent cultural (and, particularly, literary) lives. Undoubtedly, North Africa and Gaul stood out for achieving the highest cultural and educational levels.

In their golden age of economy and culture, the North African provinces played the leading role during the second and third centuries in both the spiritual and political spheres. By the middle of the third century, North Africa was economically one of the most highly developed regions of the Roman Empire, firmly fixed as the most important source of agricultural products in the western part of the empire.

After Diocletian's reforms, which spread throughout the African provinces during the five or six subsequent decades of the fourth century, Africa lived in a state of inner and outer peace, interrupted neither by Berber invasions, nor by the wars fought between aspirants for the imperial throne (Warmington 1954).

By the fourth and fifth centuries, in spite of Vandal domination, the African provinces still maintained their leading positions in the cultural and educational spheres. The outward appearance of daily and cultural life of the fourth century African city, as depicted in the inscriptions and records of church authors, showed no signs of serious decay.

Teaching Greek and rhetoric was widespread not only in Carthage, but also in small towns such as Tagasta and Madavre where rhetoric schools functioned. Judging by Augustine's religious and polemic works, writers of the golden age of Roman literature were widely known. Various philosophical schools were active in the big cities, as were heated public debates (Diligenskii 1961, 44). Many prominent church authors came from this region, including Tertullian, Cyprian, Lactantius, and Augustine, as well as the secular authors Apuleius and Martianus Capella.

An acute political crisis in the Western Empire at the beginning of 
the fifth century diminished the emperor's power in North Africa. Having taken advantage of internecine wars in the Roman provinces, Vandals and Alans, led by Geiserich, sailed from the Iberian Peninsula to Africa and started the conquest of Roman territory in 429. By the year 455 (after the death of Valentinian III) Geiseric occupied the last regions belonging to the Roman Empire (Mauretania, Numidia Cirtensis, and Tripolitania), thus completing the conquest of the African imperial provinces by the Vandals.

The Vandals' conquest was not prominently reflected in the literary activity of the Roman population (not including the sharp rise in panegyrics to the new rulers). The rhetorical educational system remained unshakeable. The Vandal kings needed the support of the Roman bureaucratic apparatus and the ruling class of the African society for the foundation of their supremacy over the conquered population. This likely explains to a considerable extent the convergence of a portion of Roman nobility and the "barbarian" ruling elite under the key role of the church (Kopylov 2006).

Foreign literature even denotes this period as a "Vandal Renaissance" (Hays 2004). However, the outer features of daily and cultural life of the African city in the previous (fourth) century show neither signs of serious decay, nor a rupture with the antique tradition. Therefore, the use of such a definition does not seem entirely accurate.

Under Geiserich and his successors, many noble Romans held prominent positions at the court of the Vandal kings, in the Vandal army, and in the provincial government (Vict. Vit., I, 6; 12; 14; 16; III, 4; 10). Under King Trasamund (496-523), Carthage had many Roman poets who glorified the Vandal king in their poems and bore the title viri clarissimi, that is they belonged to the senatorial nobility: Lucsorius, Coronatus, Flavius Felix, Dracontius, and others. They all engaged in literary activity and, besides the panegyrics to barbarian kings, M. Gasparov notes that they laughed in their Latin epigrams at the new governors who permitted them to do so (Gasparov $1982,11)$. The mission of the late antique authors from North Africa consisted largely in "the return of outcast sciences to the African city" (Drac. Rom. I, 13) ("sciences" - litteras, that is literature, namely).

Generally speaking, there is nothing surprising about the leading position of the North African provinces in the imperial structure both economically and intellectually. Recall that Africa was not only the Roman agrarian "granary," but also its scientific and philosophical "granary" (Alexandrian school).

Concerning Gaul, with Lyons as its main center of Romanization, it also was a "citadel of the late antique cultural life (Albrecht 2005, 1410)." The spiritual centers were schools in Marseilles, Arle, Nimes, Toulouse, Narbonne, Vienne, Poitiers (Limonum), and Bordeaux. The last great antique poet, Decimus Magnus Ausonius, came from Gaul.

Lugudunum, an earlier capital of the province, was one of the most densely populated cities of Gaul with eighty to one hundred thousand inhabitants. Contemporaries called this city gymnasium mundi. 
Interestingly, the rhetoric competitions were held here back in the first century (Perfilova 2002, 45). The provincial elite appreciated "the literary knowledge," considering it equivalent to nobility (Sid. Epist. VIII. 1).

Gradually Gaul became the Roman cultural and educational depository, as evidenced by "the magnificent development of literature and arts in the shortsighted eyes of contemporaries," who presented the period as "the era of glory and prosperity of the native land (Grevs et al 1913, 231)". In the fourth and fifth centuries, Gaul's borderlands with Germany became a Roman outpost in the struggle against barbarians, and further strengthened the significance of this province in the Latin Western world.

Gaul also produced numerous remarkable Christian authors, among them Salvianus of Marseilles; Sulpicius Severus; Paulinus of Nola, the founder of the Christian poetic tradition; and Gregorius Turonensis. In the fifth century the Romans lost Gaul, but under the power of German kings, oratory schools and representatives of the intellectual elite of Gallic-Roman society, such as Sidonius Apollinaris, continued their activity.

What made it possible for Gaul to become the last stronghold of the dying empire not only in military and administrative terms, but also intellectually? The answer to this question can be found in the epoch of Caesar and Augustus.

Researchers typically emphasize that Celtic civitas was preserved almost entirely intact during Roman times (Jullian 1914, 362). The only element changed by the Romans was the organization of Gaul's administration according to the Roman model (Gaxotte 1951, 68-69). In addition, the changing character and role of the city center was an important modification to the previous organization of civitas in the Roman period. This was connected to the Roman policy of consolidating the local aristocracy, which Rome saw as a natural support for its power in the provinces.

In the first centuries A.D., Gaul experienced a rapid growth of its cities. A policy of urbanization was particularly strong during the reigns of Caesar and August. French historian A. Grenier refers to this period as the great epoch of founding cities, the most significant and brilliant Renaissance in the history of France (Grenier 1931, 689-690). The city became the base for Romanization and Roman influence over the entire community. It was the essence of Roman urbanization policy and the municipalization of the city structure. In this regard, the city in the Roman epoch lay at the heart of economic, political, and cultural life in Gaul, the center of Roman influence on the local community. Due to Roman influence, Gallo-Roman society acquired a certain outer administrativepolitical and inner social structure through the establishment of the Roman municipal system.

Here the significance of the intellectual provincial elite in the Late Antique period should be clarified. Independence and artistic freedom was hard to preserve in the context of almost absolute imperial power. 
Moreover, because of Rome's large-scale conquests throughout its history, the Empire itself was gradually changing. It was becoming less and less "Roman," that is marked by Rome and Italy, and instead more and more universal.

The "Imperial" aristocracy, having come from the provinces, dominated in Rome, and the city itself lost part of its historical supremacy as a result (Hanoune and Scheid 2004, 27). By the beginning of the fourth century Rome ceased to be the political center not only of the whole Roman Empire, but of its Western part as well. Emperors began to use Milan, Trier, Constantinople, and Ravenna as imperial residences instead.

The provincial elite, having replaced the old Roman aristocracy, longed to preserve the eternal ideal, inseparable in their opinion from Rome. In the era of Domitianus and Trajan, the upstarts Pliny the Younger and Tacitus, having both come from Cisalpine Gaul (the former definitely came from there; for the latter it is merely supposition), were more ardent supporters of tradition than the last representatives of famous families dating back to Hannibal.

In Late Antiquity, such representatives of the intellectual elite as Apollinaris Sidonuis, Symmachus, and Claudius Rutilius Namatianus succeeded Pliny and Tacitus to preserve Roman identity. These people were united not only by their status as Roman nobility, but by the system of rhetorical upbringing and education, the "paideia" of the Roman model, which cultivated both a cognitive component of consciousness and a whole system of social and cultural values typical for classical antiquity. Practically all late antique authors were rhetorically educated and, consequently, were inclined to self-expression in the arts (and particularly, in literature). In addition, all of them spoke the same language, Latin, and learned and taught the same morals and aesthetics.

In regard to Latin, it should be noted that language was one of the basic components of Roman identity. Considering language as "the means of creating thought," the Russian philologist A. A. Potebnia has proven that the language of every nation creates unique systems of thought and mentality, and influences the formation of symbolism and values (Potebnia 1892 , ch. 3), which undoubtedly affected the formation of the provincial Roman elite.

One last, but by no means least important component of Roman identity was the adherence to the idea of the immortality of the Empire and Rome, "the eternal city." A. Toynbee notes that the word "eternity" is the most common phrase (for example, the poets use "Aeternitas Romae" or simply "Urbs" instead of Rome) not only in Latin, but in Greek as well right before the fall of Rome. Even after the sack of Rome by Alaric the speech of this city's immortality still can be heard (Toynbee 1991, 391).

As P. Courcelle accurately remarks, after the catastrophe at Adrianople a sudden awareness of deadly threat loomed above the empire and brought new strength to the patriotic mood (Courcelle 1964, 134-161). It also instilled new life in the concept of Aeternitas Romae, as evidenced in 
numerous literary works of this period (Auson. Cons. Orat.; De omen.; De urb.; Orat. Laud. ad Caes. Grat.; Prud. Cl. Lib. Peristeph.; Rut. Nam. De red. suo; Amm. Marc. XIV; Sid. Epist. II.; IV ). This feeling undoubtedly came from admiration for Rome's past and from the traditions of small provincial towns, which often adored their idealized neighbour Rome, a sentiment instilled in them during their education by rhetoricians and philosophers.

Ancient moral values were taught in the Latin rhetoric schools (from the first century A.D.) through a curriculum founded on the study of classical literary works, whose plot lines revolved around ancestors' heroic deeds and the highly moral actions of previous generations of political leaders. Thus cultural space, in particular the rhetoric schools, played a factor in the preservation of traditional values from the imperial golden age during Late Antiquity.

In the fifth century, shifting from Gaul and North Africa to the independent barbarian states, the main factors in preserving the classical tradition were "the vitality" of the Roman state structures - the Senate, the magistrates, and the law (Boethius, for example, served as magister officiorum under King Theodorich, and held the leading position in the Senate, which still functioned even under the Ostrogoths (Ukolova 1989, 32)), and the preservation of the Latin language as the living language of the late antique ethnos (Russel 1958) (roughly until the mid-sixth century).

Translated from Russian by Irina O. Eshchenko and Emily B. Baran

\section{REFERENCES}

1. Warmington, Brian H. 1954. The North African Provinces from Diocletian to the Vandal Conquest. Cambridge: Cambridge Univ. Press.

2. Diligenskii, G. G. 1961. Severnaia Afrika $v I V-V v v$. [Northern Africa in the $4^{\text {th }}-5^{\text {th }}$ Centuries]. Moscow: Nauka publ.

3. Kopylov, I. A. 2006. "Tserkov' v sisteme organizatsii vlasti i obshchestva v Vandal'skoi Afrike (V-VI vv.) [The Church in the Organization of Power and Society in Vandal Africa (4th-6th Cent.)]." 'Kandidat nauk' diss., Institute of World History, Russian Academy of Sciences.

4. Hays, Gregory. 2004. "Romuleis Libicisque litteris: Fulgentius and the 'Vandal Renaissance'." In Vandals, Romans and Berbers: New Perspectives on Late Antique North Africa. Burlington, VT: Ashgate.

5. Gasparov, M. L. 1982. "Poeziia ritoricheskogo veka [Poetry of the Rhetoric Age]." In Pozdniaia latinskaia poeziia [Late Roman Poetry]. Moscow: Khudozh. lit.

6. Albrecht, Michael von. 2005. Istoriia rimskoi literatury [A History of Roman Literature]. Translated by A. I. Liubzhin. Vol. 3. Moscow: "Greko-latinskiy cabinet" Iu. A. Shichalina. Original publication: Michael von Albrecht. 1994. Geschichte der römischen Literatur. München: Deutscher Taschenbuch-Verlag.

7. Perfilova, T. B. 2002. "Organizatsiia uchebnoi deiatel'nosti v grammaticheskikh i ritoricheskikh shkolakh Gallii v IV-V vekakh [The Organization of Study in Grammar and Rhetorical Schools in Gaul in the 4th $5^{\text {th }}$ Cent.]", Iaroslavskii pedagogicheskii vestnik [Iaroslavl Pedagogical Bulletin] 4 (33): 42-50. 
8. Grevs, I. M., F. F. Zelinskii, N. I. Kareev, M. I. Rostovtsev, eds. 1913. "Istoriia Frantsii v rannee srednevekov'e [A History of France in the Early Middle Ages]." Obshchaia istoriia evropeiskoi kul'tury [General History of European Culture]. Vol. VII. Sankt Petersburg: Brokgauz-Efron.

9. Jullian, Camille. 1914. Histoire de la Gaule. Vol. IV. Paris: HACHETTE et Cie.

10.Gaxotte, Pierre. 1951. Histoire des Franqais, Vol. I. Paris: Flammarion.

11.Grenier, Manuel A. 1931. d'Archeologie gallo-romaine. Vol. V. Paris: Picard.

12.Hanoune, Roger, and John Scheid. 2004. Tsivilizatsiia Drevnego Rima [Ancient Roman Civilization]. Translated by I. S. Borodycheva and A. A. Kitaitseva. Moscow: AST publ. Original publication: Hanoune, Roger, et John Scheid. 1995. Nos ancetres les romains. Paris: Gallimard (Editions).

13.Woolf, Greg. 1998. Becoming Roman: The Origins of Provincial Civilization in Gaul. Cambridge: Cambridge Univ. Press.

14.Potebnia, A. A. 1892. Mysl' $i$ iazyk [Thought and Language]. Khar'kov: Adol'f Dare publ.

15.Toynbee, Arnold J. 1991. Postizhenie istorii. Abridged one-volume edition compiled by A. P. Ogurtsov. Moscow: Progress publ. Original publication: Toynbee, Arnold J. 1934-1961. A Study of History. In 12 vols. Oxford: Oxford University Press.

16.Courcelle, Pierre P. 1964. Histoire littéraire des grandes invasions germaniques. Paris: Études augustiniennes.

17.Ukolova, V. I. 1989. Antichnoe nasledie i kul'tura rannego srednevekov'ia [Antique Heritage and Culture of the Early Middle Ages]. Moscow: Nauka publ.

18.Russel, Josiah C. 1958. Late Ancient and Medieval Population. Philadelphia: The American Philosophical Society. 